\title{
Allogeneic stem cell transplantation after fludarabine, melphalan and thymoglobulin followed by early withdrawal of prophylactic immunosuppression could be an effective approach to patients with acute lymphoblastic leukemia
}

\author{
L. RAIDA ${ }^{1 *}$, Z. RUSINAKOVA ${ }^{1}$, R. SZOTKOWSKA ${ }^{1}$, A. KUBA ${ }^{1}$, E. FABER ${ }^{1}$, P. ROHON ${ }^{1}$, T. SZOTKOWSKI ${ }^{1}$, J. HUBACEK ${ }^{1}$, Z. PIKALOVA ${ }^{1}$, \\ M. JAROSOVA ${ }^{1}$, M. DIVOKA ${ }^{1}$, K. INDRAK ${ }^{1}$, K. LANGOVA ${ }^{2}$, I. SKOUMALOVA ${ }^{1}$, T. PAPAJIK ${ }^{1}$ \\ ${ }^{1}$ Department of Hemato-Oncology, University Hospital and Faculty of Medicine and Dentistry, Palacky University, Olomouc, Czech Republic; \\ ${ }^{2}$ Department of Biophysics, Faculty of Medicine and Dentistry, Palacky University, Olomouc, Czech Republic \\ ${ }^{*}$ Correspondence: raidal@volny.cz
}

Received December 16, 2014 / Accepted May 11, 2015

\begin{abstract}
Presented are results of allogeneic hematopoietic stem cell transplantations (HSCTs) in 13 patients with high-risk acute lymphoblastic leukemia (ALL) in the first complete remission after a reduced intensity conditioning combining fludarabine $\left(150 \mathrm{mg} / \mathrm{m}^{2}\right)$ and melphalan $\left(140 \mathrm{mg} / \mathrm{m}^{2}\right)$ with thymoglobulin $(4.5 \mathrm{mg} / \mathrm{kg})$. The immunosuppressive effect of T-cell depletion reducing the risk of graft-versus-host disease (GVHD) and non-relapse mortality was compensated by early initiation of reduction and withdrawal of prophylactic immunosuppression aimed at maintaining effective immunological antileukemic control. The median post-transplant follow-up was 23 (range, 10-65) months. Stable engraftment of donor's hematopoiesis was achieved in all patients. Acute GVHD was observed in two cases (15.4\%); the chronic form was not noted. Two patients (15.4\%) relapsed with ALL at 3 and 16 months after transplantation. During the above post-transplant follow-up, all 13 recipients were alive, with a probability of 2-year disease-free survival of 76.9\% (95\% CI 51-100\%). Although the results were obtained with a small pilot study group it may be assumed that, given the prognostic risk of most patients and the nearly 2-year median post-transplant follow-up, the approach may be considered as an alternative to HSCTs after traditional myeloablative or reduced conditioning regimens with standard GVHD prophylaxis.
\end{abstract}

Key words: acute lymphoblastic leukemia, allogeneic hematopoietic stem cell transplantation, fludarabine, melphalan, thymoglobulin, graft-versus-host disease prophylaxis

Allogeneic HSCT is an important treatment modality in patients with ALL [1-3]. In this highly aggressive hematological malignancy, transplantations after intensive standard myeloablative conditionings (e.g. busulfan and cyclophosphamide or total body irradiation and cyclophosphamide) may be assumed to reduce the risk of its post-transplant relapse or progression. However, increased organ regimen-related toxicity (RRT) and non-relapse mortality (NRM) may negatively influence the survival of patients receiving this therapy. In contrast, the lower cytoreductive potential of reduced intensity conditioning (RIC), albeit with a less complicated immediate post-transplant course, results in insufficient suppression of the residual leukemic clones $[4,5]$. In the case of standard immunosuppressive prevention of GVHD, with its withdrawal initiated as late as approximately on day +100 after HSCT, graft-versus-leukemia (GVL) reaction may also be suppressed for a relatively long time. In combination with the lower reduction of the residual leukemic clones following RIC, this may lead to a higher post-transplant recurrence of ALL.

An RIC regimen combining fludarabine $\left(150 \mathrm{mg} / \mathrm{m}^{2}\right)$ with myelotoxic and lymphotoxic melphalan $\left(140 \mathrm{mg} / \mathrm{m}^{2}\right)$ has been long used globally. It has a potential for significant immediate cytoreduction which appears necessary for effective post-transplant control of ALL. Gastrointestinal mucosal RRT following administration of melphalan in the above doses may, however, be reflected in a higher incidence of both acute and chronic GVHD with a significantly increased risk of NRM $[6,7]$. Severe and prolonged "in vivo" T-cell depletion with alemtuzumab added to the fludarabine/melphalan (FM) combination significantly reduces the risk for the development of GVHD and NRM [8], but often at a cost of delayed 
achievement of complete donor chimerism [9] and insufficient GVL reaction with a need for subsequent administration of donor lymphocyte infusions (DLIs). "In vivo" T-cell depletion may also be achieved with antithymocyte globulin (ATG) in a conditioning regimen. Although it reduces the risk for severe immunological complications and NRM it is usually not as prolonged (depending on the ATG used and its total dose) and leading to long-term negative effects on donor immunocompetent cells as after alemtuzumab. Given the above experiences and assumptions, a decision was made that ALL patients in the first complete remission (CR) considered for allogeneic HSCT would undergo conditioning with the aforementioned standard FM combination with added thymoglobulin at a total dose of $4.5 \mathrm{mg} / \mathrm{kg}$. With respect to the higher risk of recurrence of the underlying disease with high proliferative potential, due to either less intensive conditioning or negative effects of T-cell depletion with ATG on GVL reaction, however, the comprehensive post-transplant approach to the patients also included early reduction and withdrawal of GVHD prevention with cyclosporin A (CyA). This brief communication presents the first experiences with the above approach in a group of patients with allogeneic transplantation for high-risk ALL in CR.

\section{Patients and methods}

Patients and pre-transplant treatment. The study comprised 13 adult patients with a median age at diagnosis of 34 (range, 24-57) years, available for a post-transplant followup of at least 6 months. Allogeneic HSCT was indicated for primary ALL in the first CR in 12 patients; one participant (patient No.13) was transplanted for lymphoblastic trans-

Table 1. Patients' characteristics of primary disease and pre-transplant treatment

\begin{tabular}{|c|c|c|c|c|c|c|c|c|}
\hline $\begin{array}{l}\text { patient } \\
\text { No. }\end{array}$ & gender & $\begin{array}{l}\text { age at } \\
\text { diagnosis } \\
\text { (years) }\end{array}$ & $\begin{array}{l}\text { type } \\
\text { of } \\
\text { ALL }\end{array}$ & cytogenetic findings at diagnosis ${ }^{*}$ & $\begin{array}{l}\text { WBC } \\
\text { at diagnosis } \\
\left(\times 10^{9} / \mathrm{L}\right)\end{array}$ & $\begin{array}{l}\text { extramedullary } \\
\text { involvement } \\
\text { at diagnosis }\end{array}$ & $\begin{array}{l}\text { primary } \\
\text { therapeutic } \\
\text { protocol }\end{array}$ & $\begin{array}{l}\text { time from } \\
\text { diagnosis } \\
\text { to HSCT } \\
\text { (months) }\end{array}$ \\
\hline 1 & female & 24 & common B & $46, \mathrm{XX}, \mathrm{t}(12 ; 22)(\mathrm{p} ? 12 ; \mathrm{q} ? 13)[4] / 46, \mathrm{XX}[16]$ & 8.5 & none & CALGB & 6 \\
\hline 2 & male & 50 & common B & $\begin{array}{l}\text { standard cytogenetic methods unsuccessful, } \\
\text { BCR-ABL1fusion with a breakpoint in the minor } \\
\text { region was confirmed by molecular genetic meth- } \\
\text { ods }\end{array}$ & 2.4 & none & $\begin{array}{l}\text { CALGB } \\
+ \text { imatinib }\end{array}$ & 5 \\
\hline 3 & male & 57 & common B & $\begin{array}{c}52, \mathrm{XY},+\mathrm{X},+10, \operatorname{der}(14) \mathrm{t}(8 ; 14)(\mathrm{q} ? 12 ; \mathrm{q} 32.3),+17,+20 \\
+21,+21[15] / \\
46, \mathrm{XY}[5]\end{array}$ & 5.37 & none & CALGB & 5 \\
\hline 4 & female & 34 & pre-B & $46, \mathrm{XX}, \operatorname{der}(20) \mathrm{t}(1 ; 20)(\mathrm{q} ? 21 ; ?)[3] / 46, \mathrm{XX}[10]$ & 2.39 & none & GMALL & 7 \\
\hline 5 & female & 25 & pre-B & 46,XX,t(X;6)(p?21;p?23),del(9)(p21)[19]/46,XX[1] & 34.3 & none & GMALL & 6 \\
\hline 6 & female & 34 & pre-B & $\begin{array}{c}47, \mathrm{XX}, \mathrm{t}(4 ; 11)(\mathrm{q} 21 ; \mathrm{q} 23),+\operatorname{der}(4) \mathrm{t}(4 ; 11)(\mathrm{q} 21 ; \mathrm{q} 23) \\
{[60] /} \\
48, \mathrm{XX},+\operatorname{der}(\mathrm{X}) ? \operatorname{del}(\mathrm{X})(\mathrm{q} ? 24), \mathrm{t}(4 ; 11)(\mathrm{q} 21 ; \mathrm{q} 23) \\
+\operatorname{der}(4) \mathrm{t}(4 ; 11)(\mathrm{q} 21 ; \mathrm{q} 23)[11]\end{array}$ & 14.19 & none & GMALL & 4 \\
\hline 7 & male & 39 & common B & $46, \mathrm{XY}[18]$ & 5.92 & CNS & GMALL & 5 \\
\hline 8 & male & 28 & pre-T & $46, \mathrm{XY}[6]$ & 10.76 & $\begin{array}{l}\text { retroperitoneal } \\
\text { lymph nodes }\end{array}$ & GMALL & 5 \\
\hline 9 & male & 25 & $\begin{array}{l}\text { medul- } \\
\text { lary T }\end{array}$ & $\begin{array}{c}46, \mathrm{XY}, \operatorname{del}(9)(\mathrm{p} 21) 3[3] / 47, \mathrm{XY},+6, \operatorname{del}(9)(\mathrm{p} 21)[3] / \\
46, \mathrm{XY}[7]\end{array}$ & 11.95 & pericardium ${ }^{\star *}$ & GMALL & 6 \\
\hline 10 & female & 25 & pre- $\mathrm{T}$ & $47, \mathrm{XX},+4[11] / 46, \mathrm{XX}[1]$ & 1.23 & none & GMALL & 6 \\
\hline 11 & male & 25 & common B & $\begin{array}{c}69, \mathrm{XY},+\mathrm{X},+\mathrm{Y},+2,+4,+5,+5,+6,+8, \mathrm{t}(9 ; 22) \\
(\mathrm{q} 34 ; \mathrm{q} 11.2),+10,+10, \\
+11,+13,+14,+14,+15,+16,+17,+18,+19,+20,+20,+ \\
21,+\operatorname{der}(22) \\
\mathrm{t}(9 ; 22)(\mathrm{q} 34 ; \mathrm{q} 11.2)[35] / 46, \mathrm{XY}[2]\end{array}$ & 5.42 & none & $\begin{array}{l}\text { GMALL } \\
+ \text { imatinib }\end{array}$ & 6 \\
\hline 12 & male & 42 & common B & 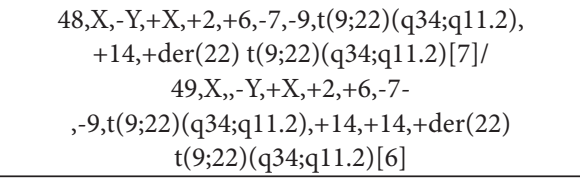 & 22.6 & none & $\begin{array}{l}\text { GMALL } \\
+ \text { imatinib }\end{array}$ & 7 \\
\hline 13 & male & 40 & $\begin{array}{l}\text { common } \\
\mathrm{B}^{* * *}\end{array}$ & $\begin{array}{c}51, \mathrm{XY},+\mathrm{Y},+2,+5,+6,-7, \mathrm{t}(9 ; 22)(\mathrm{q} 34 ; \mathrm{q} 11) \operatorname{inv}(9) \\
(\mathrm{p} 13 ; \mathrm{q} 34.3),+10,+\operatorname{der}(22) \mathrm{t}(9 ; 22)(\mathrm{q} 34 ; \mathrm{q} 11)\end{array}$ & 15.63 & none & $\begin{array}{l}\text { GMALL } \\
+ \text { dasatinib }\end{array}$ & 5 \\
\hline
\end{tabular}

CNS - central nervous system , ${ }^{*}$ evaluated by classical cytogenetic methods and fluorescence in situ hybridization, ${ }^{* *}$ manifestation of mediastinal mass at diagnosis, ${ }^{* *}$ (lympho)blastic crisis of CML 
formation of chronic myeloid leukemia (CML) but given his induction therapy which, after the diagnosis had been made, was identical to the approach in primary Philadelphia chromosome positive $(\mathrm{Ph}+) \mathrm{ALL}$, he was included in this pilot study. This patient achieved molecular remission of the disease after induction chemotherapy in combination with the tyrosine kinase inhibitor (TKI) dasatinib. The basic characteristics of all patients and their prognostic parameters including primary treatment protocols are shown in Table 1. Standard induction or consolidation chemotherapy was administered in accordance with the Cancer and Leukemia Group B (CALGB) 8811 or German Multicenter Study Group for Adult ALL (GMALL) 07/2003 protocols $[10,11]$. In Ph+ ALL patients, TKIs were added to their standard treatment. The median time interval from diagnosis to HSCT was 6 months (range, 4-7 months). Nine patients (69.2\%) receiving transplantation from unrelated donors underwent two chemotherapy cycles in addition to successful induction therapy according to the primary protocol. Four patients (30.8\%) with a readily available donor underwent only one consolidation therapy cycle. However, there was no significant difference in the interval from diagnosis to HSCT as in two patients subsequently transplanted from related available donors, consolidation chemotherapy had to be postponed due to serious infectious complications during induction therapy. All patients gave signed informed consent with the transplant procedure approved by the institutional review board.

Conditioning regimen. The conditioning regimen consisted of fludarabine ( $30 \mathrm{mg} / \mathrm{m}^{2}$ on days $-8,-7,-6,-5$ and -4$)$, melphalan $\left(70 \mathrm{mg} / \mathrm{m}^{2}\right.$ on days -3 and -2$)$ and thymoglobulin $(1.5 \mathrm{mg} / \mathrm{kg}$ on days $-4,-3$ and -2$)$.

HSCT. On day 0, all 13 patients received donor peripheral blood stem cells. Stem cells from HLA-matched related do- nors (MRDs) or a mismatched related donor (MMRD) were transplanted to 3 patients $(23.1 \%)$ and 1 patient $(7.7 \%)$, respectively. However, most HSCTs were from unrelated donors. Grafts from HLA-matched unrelated donors (MUDs) and mismatched unrelated donors (MMUDs) were transplanted to 3 recipients (23.1\%) and 6 recipients (46.2\%), respectively. The donors' median age was 29 years (range, 19-51 years). These characteristics and parameters, as well as gender of donors and recipients, their cytomegalovirus (CMV) serologic status, $\mathrm{ABO} / \mathrm{Rh}$ compatibility, the number of hematopoietic stem cells in the graft are shown in Table 2. The median numbers of transfused mononuclear cells (MNCs) and CD34+ cells in the graft were 6.37 (range, 3.94-9.85) $\times 10^{8} / \mathrm{kg}$ and 4.9 (range, $2.94-10.12) \times 10^{6} / \mathrm{kg}$, respectively.

Post-transplant GVHD prophylaxis. As part of posttransplant GVHD prophylaxis, all patients were given CyA. Its intravenous administration was initiated on day -1 at a dose of $6 \mathrm{mg} / \mathrm{kg} /$ day which was subsequently adjusted so that the target plasma concentration ranged between 200 and $300 \mathrm{ng} /$ $\mathrm{mL}$. The recipients were switched to the oral form of CyA only after manifestations of gastrointestinal RRT resolved. CyA dose reduction with a gradual decrease of its plasma concentrations was planned to be started, in the absence of any possible manifestations of GVHD or ALL relapse, between days +28 and +35 . The target was full withdrawal of CyA on days +90 to +110 . When grafts from HLA-mismatched donors were transplanted, CyA was initially combined with methotrexate (MTX) or mycophenolate mofetil (MMF) in 1 (7.7\%) and 6 (46.2\%) recipients, respectively (Table 2 ). MTX was administered at doses of $15 \mathrm{mg} / \mathrm{m}^{2}$ on day +1 and $10 \mathrm{mg} / \mathrm{m}^{2}$ on days $+3,+6$ and +11 . The administration of MMF was initiated on day +1 at a dose of $30 \mathrm{mg} / \mathrm{kg} /$ day that was gradually reduced so that the drug was withdrawn on days +15 to +56 . As was

Table 2. Stem cell transplantations characteristics

\begin{tabular}{|c|c|c|c|c|c|c|c|c|c|c|}
\hline $\begin{array}{l}\text { patient } \\
\text { No. }\end{array}$ & $\begin{array}{l}\text { donor } \\
\text { type }\end{array}$ & $\begin{array}{c}\text { donor } \\
\text { age } \\
\text { (years) }\end{array}$ & $\begin{array}{l}\text { gender } \\
(\mathrm{R} / \mathrm{D})\end{array}$ & $\begin{array}{c}\mathrm{ABO} / \mathrm{Rh} \\
(\mathrm{R} / \mathrm{D})\end{array}$ & $\begin{array}{c}\text { CMV serostatus } \\
\text { (R/D) }\end{array}$ & $\begin{array}{l}\text { infused MNC } \\
\left(\times 10^{8} / \mathrm{kg}\right)\end{array}$ & $\begin{array}{c}\text { infused CD34+ } \\
\text { cells }\left(\times 10^{6} / \mathrm{kg}\right)\end{array}$ & $\begin{array}{l}\text { post-trans- } \\
\text { plant GVHD } \\
\text { prophylaxis }\end{array}$ & $\begin{array}{c}\text { start of CyA } \\
\text { reduction } \\
\text { (day) }\end{array}$ & $\begin{array}{c}\text { stop of CyA } \\
\text { (day) }\end{array}$ \\
\hline 1 & MMUD & 41 & $\mathrm{~F} / \mathrm{M}$ & $\mathrm{B}+/ \mathrm{O}+$ & $+/-$ & 6.37 & 4.46 & CyA + MMF & +77 & +195 \\
\hline 2 & MUD & 24 & $\mathrm{M} / \mathrm{M}$ & $\mathrm{AB}+/ \mathrm{O}-$ & $+/-$ & 5.28 & 7.59 & СуА & +46 & +113 \\
\hline 3 & MUD & 35 & $\mathrm{M} / \mathrm{M}$ & $\mathrm{A}+/ \mathrm{A}-$ & $+/+$ & 6.75 & 7.0 & СуA & +50 & +110 \\
\hline 4 & MUD & 51 & $\mathrm{~F} / \mathrm{M}$ & O-/O- & $-1-$ & 3.94 & 5.04 & СуА & +46 & +108 \\
\hline 5 & MMUD & 29 & $\mathrm{~F} / \mathrm{M}$ & $\mathrm{O}-/ \mathrm{O}+$ & $-1+$ & 9.85 & 10.12 & CyA + MTX & +70 & +92 \\
\hline 6 & MRD & 41 & $\mathrm{~F} / \mathrm{F}$ & $\mathrm{B}+/ \mathrm{AB}+$ & $+/+$ & 4.5 & 4.61 & СуА & +30 & +108 \\
\hline 7 & MMRD & 38 & $\mathrm{M} / \mathrm{M}$ & $\mathrm{AB}+/ \mathrm{AB}+$ & $-1-$ & 6.48 & 3.0 & $\mathrm{CyA}+\mathrm{MMF}$ & +33 & +116 \\
\hline 8 & MMUD & 43 & $\mathrm{M} / \mathrm{M}$ & $\mathrm{O}+/ \mathrm{A}+$ & $+/+$ & 5.58 & 5.05 & $\mathrm{CyA}+\mathrm{MMF}$ & +33 & +111 \\
\hline 9 & MRD & 23 & $\mathrm{M} / \mathrm{M}$ & $\mathrm{A}+/ \mathrm{O}+$ & $+/-$ & 7.56 & 5.56 & СуА & n.a & n.a. \\
\hline 10 & MMUD & 19 & $\mathrm{~F} / \mathrm{F}$ & $\mathrm{A}+/ \mathrm{A}+$ & $+/+$ & 5.28 & 4.01 & $\mathrm{CyA}+\mathrm{MMF}$ & +56 & +105 \\
\hline 11 & MRD & 27 & $\mathrm{M} / \mathrm{M}$ & $\mathrm{B}-/ \mathrm{AB}+$ & $-1-$ & 8.27 & 3.53 & СуA & n.a. & n.a. \\
\hline 12 & MMUD & 20 & $\mathrm{M} / \mathrm{F}$ & $\mathrm{B}+/ \mathrm{O}+$ & $+/+$ & 4.83 & 2.94 & CyA + MMF & +60 & +120 \\
\hline 13 & MMUD & 23 & $\mathrm{M} / \mathrm{F}$ & $\mathrm{A}+/ \mathrm{A}+$ & $+1+$ & 7.05 & 4.9 & CyA + MMF & +60 & +113 \\
\hline
\end{tabular}

$R$ - recipient, $D$ - donor, $M R D$ - matched related donor, $M M R D$ - mismatched related donor, $M U D$ - matched unrelated donor, $M M U D$ - mismatched unrelated donor, $F$ - female, $M$ - male, $A B O / R h$ - blood groups (ABO and Rh system), CyA - cyclosporin A, $M M F$ - mycophenolate mofetil, n.a. - not applicable because of GVHD development 
the case of CyA, MMF was first administered intravenously and the patients were switched to the oral form only after resolution of gastrointestinal RRT.

Anti-infectious prophylaxis. Co-trimoxazole was administered at a dose of $960 \mathrm{mg}$ twice daily orally on days -8 to -1 . From day 0 , it was withdrawn until the absolute neutrophil count (ANC) reached $\geq 0.5 \times 10^{9} / \mathrm{L}$. Then, co-trimoxazole was continued at the same daily dose on two days a week. Herpes virus infections were prevented by $2 \times 500 \mathrm{mg}$ of oral valacyclovir or $3 \times 250 \mathrm{mg}$ of intravenous acyclovir daily, starting from day -8 . Anti-infectious prophylaxis with both co-trimoxazole and valacyclovir or acyclovir was withdrawn 6 months after immunosuppression withdrawal and in the absence of any form of GVHD. Fluconazole at a daily dose of $200 \mathrm{mg}$ orally or intravenously was initiated on day -8 and withdrawn at the moment of a stable ANC $\geq 1.0 \times 10^{9} / \mathrm{L}$, absent GVHD and if there was no need to continue with administration of broad-spectrum antibiotics or corticosteroids. Patients with a history of confirmed or suspected systemic fungal infections received secondary antifungal prophylaxis, namely voriconazole or posaconazole at daily doses of $200 \mathrm{mg}$ and $3 \times 200 \mathrm{mg}$, respectively. Gastrointestinal decontamination was performed with $2 \times 400 \mathrm{mg}$ daily of rifaximin from day -8 until a stable ANC $\geq 0.5 \times 10^{9} / \mathrm{L}$, complete resolution of mucositis and withdrawal of broad-spectrum antibiotics. $\mathrm{CMV}$-seronegative recipients transplanted from CMV-seronegative donors were substituted with leukodepleted blood products (erythrocytes and platelets). CMV-seropositive patients or CMV-seronegative ones transplanted from CMVseropositive donors were regularly screened for the presence of CMV DNA in plasma once weekly until day +100 after HSCT, so that the risk for development of CMV disease could be eliminated by early initiation of preemptive therapy. If patients developed GVHD or were treated with corticoids or intensive immunosuppressive therapy, this regular monitoring was continued past day +100 .

RRT. Non-hematological RRT was assessed according to the National Cancer Institute Common Toxicity Criteria, version 2.0 [12].

Hematopoietic recovery, engraftment and therapeutic response. Post-transplant hematopoietic recovery was defined as the first of three subsequent days with a stable ANC $\geq 0.5$ $\times 10^{9} / \mathrm{L}$ and platelets (PLTs) count $\geq 20 \times 10^{9} / \mathrm{L}$ in recipients' peripheral blood. Cellular chimerism was assessed in peripheral blood nucleated cells and bone marrow aspirate on days $+15,+60,+270$ and $+30,+90,+180,+360$, respectively, using amplification of microsatellite DNA short tandem repeats (STR) with fluorescently labeled primers in polymerase chain reaction and subsequent separation by capillary electrophoresis. Prior to HSCT, blood samples were collected from both recipients and donors and their STR profiles were determined. Those were used in the post-transplant period to quantify donor chimerism [13]. Complete donor chimerism was defined as $100 \%$ of donor nucleated cells in peripheral blood or bone marrow. Post-transplant relapses of ALL was confirmed if fol- lowing criteria had been fulfilled: $>5 \%$ of original recipient's pathological lymphoblasts in bone marrow (with or without their finding in peripheral blood, decreased hemoglobin level, ANC and PLTs) and/or proven extramedullary involvement (e.g. leukemic cells in cerebrospinal fluid or proven pathological lymphoblastic infiltration of any tissue).

GVHD diagnosis and assessment. Acute or chronic GVHD was diagnosed based on the clinical features, laboratory findings and histological results from biopsy samples of the affected tissue. Acute GVHD stages and grades were determined in accordance with standard criteria [14]. When assessing chronic GVHD, the original classification into limited and extensive forms was used based on the extent and intensity [15].

Statistical analysis. The Kaplan-Meier method was used to calculate disease-free survival (DFS), defined as the interval from HSCT to relapse of the disease or death from any cause. The analysis was carried out using the SPSS, version 15 software (SPSS Inc., Chicago, USA).

\section{Results}

Mucositis (stomatitis and/or gastrointestinal involvement) as the dominant manifestation of non-hematologic RRT was observed in 9 patients (69.2\%); in only three cases (23.1\%), however, grade III RRT was noted. Renal and liver RRT, not more severe than grade I, developed in 5 recipients (38.5\%) and 2 recipients $(15.4 \%)$, respectively (Table 3 ).

Successful engraftment was achieved in all patients. Stable ANC $\geq 0.5 \times 10^{9} / \mathrm{L}$ and PLT $\geq 20 \times 10^{9} / \mathrm{L}$ were achieved at a median time of 15 days (range, 12-17 days) and 11 days (range, 9-13 days) after HSCT. Complete donor chimerism on day +30 was detected in 12 recipients (92.3\%) (Table 3 ).

In 11 assessable patients (84.6\%), dose reduction and full withdrawal of CyA were within a median of 56 (range, 30-77) and 111 (range, 92-195) days after HSCT, respectively (Table 2 ). The delays were associated with the laboratory findings and/or symptoms that could have been linked to the development of GVHD in 8 patients (61.5\%) and 6 patients $(46.2 \%)$, respectively. However, the complication was not confirmed by the subsequent clinical course and examination results including histological findings. The delay and withdrawal of CyA, comparing to proposed protocol, were in the median of 25 (range, 11-42) and 5 (range, 1-85) days, respectively. In two cases $(15.4 \%)$, the early reduction and withdrawal of prophylactic immunosuppression were not carried out according to protocol due to development of acute GVHD.

The grade II and III of acute GVHD were observed in these two patients on days +30 and +26 , respectively (Table 3 ). In presented group, after HSCT with the above conditioning regimen and GVHD prophylaxis, chronic GVHD has not developed as yet.

Primary or reactivated CMV infections were observed in $1(7.7 \%)$ and $5(38.5 \%)$ patients, respectively. However, it was clinically manifested in only 2 recipients (15.4\%) (Table 3 ). 
In one case (patient No.1), CMV syndrome developed. In the other, CMV DNA was detected in both plasma and intestinal mucosa obtained by biopsy and the clinical manifestation of the infection (i.e. either CMV syndrome or gastrointestinal CMV disease) could not be reliably determined due to histologically confirmed concomitant acute GVHD (patient No.9). Following virostatic therapy, the symptoms disappeared completely in the former patient. The latter patient's condition also improved but it was more difficult to assess due to the parallel immunosuppressive therapy for acute GVHD.

In two ALL cases (15.4\%), the underlying disease relapsed 3 and 16 months after HSCT (Table 3). One case (patient No.5) was systemic relapse with both bone marrow and CNS involvement. In the other (patient No.6), isolated involvement of the CNS was noted. Both patients achieved another $\mathrm{CR}$ after second transplantation with cryopreserved hematopoietic cells obtained from the original donors. Intravenous high-dose MTX $\left(3 \mathrm{~g} / \mathrm{m}^{2}\right)$ and intrathecal treatment (MTX $15 \mathrm{mg}$, cytarabine $40 \mathrm{mg}$, dexamethason $4 \mathrm{mg}$ ) were used to reduce CNS leukemic involvement before the administration of non-myeloablative conditioning regimen FLAG-Ida (fludarabine $120 \mathrm{mg} / \mathrm{m}^{2}$, cytarabine $8 \mathrm{~g} / \mathrm{m}^{2}$, idarubicin $36 \mathrm{mg}$ ) $\mathrm{m}^{2}$ ) in both cases. CyA was the only immunosuppressant in GVHD prophylaxis after the second transplantations. Nevertheless, to enhance GVL effect, it was tapered since day +14 and withdrawn on day +42 . Subsequently, the patient with systemic relapse developed extensive chronic GVHD that regressed with combined immunosuppressive therapy; at 26 months after the second HSCT, the patient remains in CR of ALL. In the other patient, isolated CNS relapse occurred after 5 -month remission induced by the second HSCT. The third CR was achieved with chemotherapy and sequential DLIs but ALL recurred in the CNS six months later. At the time of

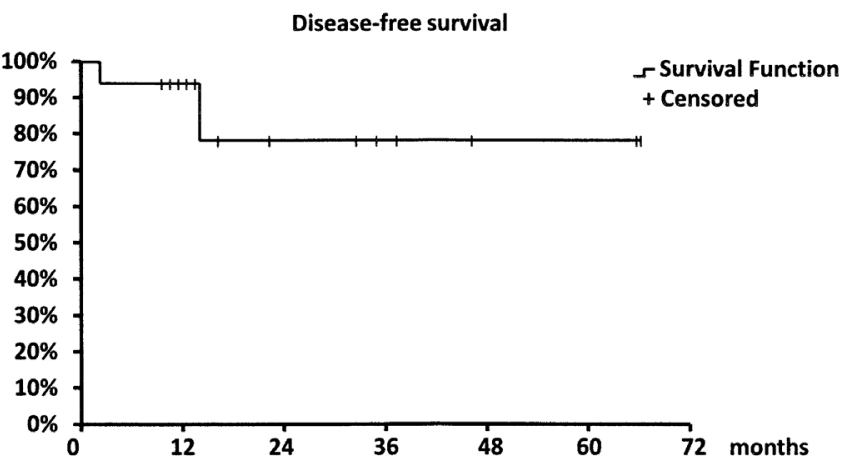

Figure 1. Estimated disease-free survival. Kaplan-Meier's curve of presented cohort .

assessment of the group, the patient was clinically stable and receiving palliative therapy.

At a median post-transplant follow-up of 23 (range, 10-65) months, NRM in the group was $0 \%$. The probability of 2-year DFS was 76.9\% (95\% CI 51-100\%) (Fig. 1). During the above post-transplant follow-up, all 13 patients were alive.

\section{Discussion}

These encouraging pilot results suggest the possibility of high curability of high-risk ALL in adult patients achieved by allogeneic HSCT performed after RIC in the first CR. However, integral parts of the treatment strategy were early reduction and withdrawal of post-transplant immunosuppressive prevention of GVHD even though these were somewhat delayed as compared with the original plan set by the proto$\mathrm{col}$. The delay stemmed from the clinical picture that could

Table 3. Patients' post-transplant outcome

\begin{tabular}{|c|c|c|c|c|c|c|c|c|}
\hline \multirow[b]{2}{*}{$\begin{array}{c}\text { patient } \\
\text { No. }\end{array}$} & \multirow[b]{2}{*}{ non-hematological RRT (grade) } & \multicolumn{3}{|c|}{ engraftment } & \multirow[b]{2}{*}{$\begin{array}{c}\text { acute } \\
\text { GVHD } \\
\text { (day, grade) }\end{array}$} & \multirow[b]{2}{*}{$\mathrm{CMV}$ reactivation } & \multirow[b]{2}{*}{$\begin{array}{l}\text { post-transplant } \\
\text { disease relapse } \\
\text { (months) }\end{array}$} & \multirow[b]{2}{*}{$\begin{array}{l}\text { post-transplant } \\
\text { follow-up } \\
\text { (months) }\end{array}$} \\
\hline & & $\begin{array}{c}A N C \geq \\
0.5 \times 10^{9} / \mathrm{L} \\
(\text { day }) \\
\end{array}$ & $\begin{array}{c}\text { PLT } \geq \\
20 \times 10^{9} / \mathrm{L} \\
(\text { day }) \\
\end{array}$ & $\begin{array}{c}\text { donor } \\
\text { chimerism } \\
\text { on day }+30 \\
\end{array}$ & & & & \\
\hline 1 & stomatitis (I), GIT (II) & +13 & +11 & $97 \%$ & no & yes (syndrome) & no & 65 \\
\hline 2 & stomatitis (II), renal (I) & +14 & +9 & $100 \%$ & no & yes (asymptomatic) & no & 65 \\
\hline 3 & renal (I) & +15 & +10 & $100 \%$ & no & no & no & 46 \\
\hline 4 & $\begin{array}{l}\text { stomatitis (III), GIT (III), renal } \\
\text { (I), liver (I) }\end{array}$ & +12 & +12 & $100 \%$ & no & no & no & 38 \\
\hline 5 & none & +17 & +12 & $100 \%$ & no & yes (asymptomatic) & yes (3) & 35 \\
\hline 6 & renal (I) & +17 & +13 & $100 \%$ & no & no & yes (16) & 32 \\
\hline 7 & stomatitis (I) & +16 & +13 & $100 \%$ & no & no & no & 23 \\
\hline 8 & stomatitis (III) & +15 & +10 & $100 \%$ & no & yes (asymptomatic) & no & 17 \\
\hline 9 & liver (I), renal (I) & +14 & +10 & $100 \%$ & yes $(+30, \mathrm{II})^{*}$ & yes* & no & 14 \\
\hline 10 & GIT (II) & +16 & +12 & $100 \%$ & no & yes (asymptomatic) & no & 13 \\
\hline 11 & stomatitis (III), GIT (III) & +15 & +11 & $100 \%$ & yes $(+26$, III $)$ & no & no & 11 \\
\hline 12 & stomatitis (I), GIT (II) & +14 & +11 & $100 \%$ & no & no & no & 10 \\
\hline 13 & stomatitis (II), GIT (II) & +13 & +11 & $100 \%$ & no & no & no & 12 \\
\hline
\end{tabular}

GIT - gastrointestinal toxicity, ${ }^{*}$ histological confirmation of acute GVHD and concomitant detection of CMV DNA in gut mucosa 
indicate developing GVHD; therefore, the possibility of this immunological complication had to be carefully ruled out prior to initiation of early reduction with CyA. Such approach was included in our proposed protocol. Nevertheless, despite presented delays of CyA reduction and withdrawal in 8 and 6 patients, respectively, the administration of post-transplant prophylactic immunosuppression was still shorter than in published studies [16, 17]. Earlier initiation of reduction (starting from days +60 and +90 in related and unrelated HSCT, respectively) and withdrawal (within 2-3 months from the initiation of reduction) of calcineurin inhibitors for GVHD prevention was reported by Cho et al. in 37 patients with high-risk ALL transplanted in the first or second CR after RIC combining fludarabine and melphalan $[15,16,18]$. The 3 -year DFS and OS rates were $62.6 \%$ and $64.1 \%$, respectively. Unlike in the present study, however, the apparent antileukemic effectiveness was accompanied by higher rates of both GVHD and NRM which could be due to less frequent administration of thymoglobulin (6 recipients transplanted from HLA-mismatched unrelated donors) and its lower total doses $(2.5 \mathrm{mg} / \mathrm{kg})$. Similar results were also reported by Stein et al. in a group of 24 ALL patients transplanted from HLA-matched related or unrelated donors after the same FM regimen [19]. T-cell depletion with ATG was performed in only one patient. GVHD was prevented by administration of tacrolimus and sirolimus or CyA and MMF; in 14 patients, MTX was added to these combinations. The time schedule of reduction and complete withdrawal of calcineurin inhibitors was not stated. The probability of 2-year DFS and OS was $61.5 \%$. However, the development of acute and chronic GVHD was observed in $75 \%$ and $86 \%$ of patients, respectively, with 2-year NRM of $21.5 \%$.

In the present study, the inclusion of "in vivo" T-cell depletion with thymoglobulin as a standard part of the above RIC was shown to influence the occurrence of GVHD as well as NRM despite the relatively high proportion of patients transplanted from HLA-mismatched donors. Even earlier withdrawal of prophylactic immunosuppression has so far not led to a significant manifestation of adverse immunological complications. However, antileukemic control with GVL reaction [20], the main goal of this post-transplant approach, was apparently maintained in most patients in spite of high-risk and even very high-risk ALL.

Acknowledgements: This work was supported by the grant MSM 6198959205 from the Czech Ministry of Education and the project IGA-LF-2015-001 of Palacky University in Olomouc.

\section{References}

[1] HUNAULT M, HAROUSSEAU JL, DELAIN M, TRUCHANGRACZYK M, CAHN JY et al. Better outcome of adult acute lymphoblastic leukemia after early genoidentical allogeneic bone marrow transplantation (BMT) than after late high-dose therapy and autologous BMT: a GOELAMS trial. Blood 2004;
104: 3028-3037. http://dx.doi.org/10.1182/blood-2003-10$\underline{3560}$

[2] GOLDSTONE AH, RICHARDS SM, LAZARUS HM, TALLMAN MS, BUCK G et al. In adults with standard-risk acute lymphoblastic leukemia, the greatest benefit is achieved from a matched sibling allogeneic transplantation in first complete remission, and an autologous transplantation is less effective than conventional consolidation/maintenance chemotherapy in all patients: final results of the International ALL Trial (MRC UKALL XII/ECOG E2993). Blood 2008; 111: 1827-1833. http://dx.doi.org/10.1182/blood-2007-10$\underline{116582}$

[3] MARKS DI, PEREZ WS, HE W, ZHANG MJ, BISHOP MR et al. Unrelated donor transplants in adults with Philadelphia-negative acute lymphoblastic leukemia in first complete remission. Blood 2008; 112: 426-434. http://dx.doi. org/10.1182/blood-2007-12-128918

[4] MOHTY M, LABOPIN M, VOLIN L, GRATWOHL A, SOCIE $\mathrm{G}$ et al. Reduced-intensity versus conventional myeloablative conditioning allogeneic stem cell transplantation for patients with acute lymphoblastic leukemia: a retrospective study from the European Group for Blood and Marrow Transplantation. Blood 2010; 116: 4439-4443. http://dx.doi. org/10.1182/blood-2010-02-266551

[5] EOM KS, SHIN SH, YOON JH, YAHNG SA, LEE SE et al. Comparable long-term outcomes after reduced-intensity conditioning versus myeloablative conditioning allogeneic stem cell transplantation for adult high-risk acute lymphoblastic leukemia in complete remission. Am J Hematol 2013; 88: 634-641. http://dx.doi.org/10.1002/ajh.23465

[6] DASGUPTA RK, RULE S, JOHNSON P, DAVIES J, BURNETT A et al. Fludarabine phosphate and melphalan: a reduced intensity conditioning regimen suitable for allogeneic transplantation that maintains the graft versus malignancy effect. Bone Marrow Transplant 2006; 37: 455-461. http://dx.doi.org/10.1038/sj.bmt.1705271

[7] RITCHIE DS, MORTON J, SZER J, ROBERTS AW, DURRANT S et al. Graft-versus-host disease, donor chimerism, and organ toxicity in stem cell transplantation after conditioning with fludarabine and melphalan. Biol Blood Marrow Transplant 2003; 9: 435-442. http://dx.doi.org/10.1016/S10838791(03)00128-9

[8] VAN BESIEN K, KUNAVAKKAM R, RONDON G, DE LIMA M, ARTZ A et al. Fludarabine-Melphalan Conditioning for AML and MDS: Alemtuzumab Reduces Acute and Chronic GVHD without Affecting Long-Term Outcomes. Biol Blood Marrow Transplant 2009; 15: 610-617. http://dx.doi. org/10.1016/j.bbmt.2009.01.021

[9] KOTTARIDIS PD, MILLIGAN DW, CHOPRA R, CHAKRAVERTY RK, CHAKRABARTI S et al. In vivo CAMPATH-1H prevents graft-versus-host disease following nonmyeloablative stem cell transplantation. Blood 2000; 96: 2419-2425.

[10] LARSON RA, DODGE RK, BURNS CP, LEE EJ, STONE $\mathrm{RM}$ et al. A Five-Drug Remission Induction Regimen With Intensive Consolidation for Adults With Acute Lymphoblastic Leukemia: Cancer and Leukemia Group B Study 8811. Blood 1995; 85: 2025-2037. 
[11] FOLBER F, SALEK C, DOUBEK M, SOUKUPOVA MAALOUFOVA J, VALOVA $\mathrm{T}$ et al. Treatment of adult acute lymphoblastic leukemia according to GMALL 07/2003 study protocol in the Czech Republic - the first experience. Vnitr Lek 2010; 56: 176-182.

[12] TROTTI A, BYHARDT R, STETZ J, GWEDE C, CORN B et al. Common toxicity criteria: version 2.0. an improved reference for grading the acute effects of cancer treatment: impact on radiotherapy. Int J Radiat Oncol Biol Phys 2000; 47: 13-47. http://dx.doi.org/10.1016/S0360-3016(99)00559-3

[13] NOLLET F, BILLIET J, SELLESLAG D, CRIEL A. Standardisation of multiplex fluorescent short tandem repeat analysis for chimerism testing. Bone Marrow Transplant 2001; 28: 511-518. http://dx.doi.org/10.1038/sj.bmt.1703162

[14] PRZEPIORKA D, WEISDORF D, MARTIN P, KLINGEMANN HG, BEATTY P et al. 1994 Consensus Conference on Acute GVHD Grading. Bone Marrow Transplant 1995; 15 : 825-828.

[15] SULLIVAN KM, AGURA E, ANASETTI C, APPELBAUM F, BADGER C et al. Chronic graft-versus-host disease and other late complications of bone marrow transplantation. Semin Hematol 1991; 8: 250-259.

[16] MOHTY M, BAY JO, FAUCHER C, CHOUFI B, BILGER K et al. Graft-versus-host disease following allogeneic transplantation from HLA-identical sibling with antithymocyte globulin-based reduced-intensity preparative regimen. Blood 2003; 102: 470-476. http://dx.doi.org/10.1182/blood-2002-12$\underline{3629}$

[17] BACHANOVA V, VERNERIS MR, DEFOR T, BRUNSTEIN CG, WEISDORF D. Prolonged survival in adults with acute lymphoblastic leukemia after reduced-intensity conditioning with cord blood or sibling donor transplantation. Blood 2009; 113: 2902-2905. http://dx.doi.org/10.1182/blood-2008-10$\underline{184093}$

[18] CHO BS, LEE S, KIM YJ, CHUNG NG, EOM KS et al. Reduced-intensity conditioning allogeneic stem cell transplantation is a potential therapeutic approach for adults with high-risk acute lymphoblastic leukemia in remission: results of a prospective phase 2 study. Leukemia 2009; 23: 1763-1770. http://dx.doi.org/10.1038/leu.2009.102

[19] STEIN AS, PALMER JM, O'DONNELL MR, KOGUT NM, SPIELBERGER RT et al. Reduced-Intensity Conditioning followed by Peripheral Blood Stem Cell Transplantation for Adult Patients with High-Risk Acute Lymphoblastic Leukemia. Biol Blood Marrow Transpl 2009; 15: 1407-1414. http://dx.doi. org/10.1016/j.bbmt.2009.07.003

[20] MEDD PG, PENIKET AJ, LITTLEWOOD TJ, PEARCE R, PERRY J et al. Evidence for a GVL effect following reducedintensity allo-SCT in ALL: a British Society of Blood and Marrow Transplantation study. Bone 